\title{
Species diversity, endemism and distribution of land snails of the Western Ghats, India
}

\author{
N. A. Aravind, ${ }^{1,2}$ K. P. Rajashekhar ${ }^{2}$ and N. A. Madhyastha ${ }^{3}$ \\ ${ }^{1}$ Ashoka Trust for Research in Ecology and the Environment (ATREE), \#659, $5^{\text {th }}$ A Main, Hebbal, \\ Bangalore, 560 024, India. Email: aravind@atree.org \\ ${ }^{2}$ Department of Applied Zoology, Mangalore University, Mangalagangothri, Mangalore, 574 199, India. \\ ${ }^{3}$ Malacology Centre, Pooma Prajna College, Udupi, 576 101, India.
}

\begin{abstract}
As elsewhere, invertebrate taxa have received little attention in conservation planning in India. The Western Ghats has been designated as a global biodiversity hotspot, one of only two such designations in India. We have assembled a database for land snail records in the region, incorporating both published records and the results of our own surveys over the last three years. Of the 269 species so far recorded, $75 \%$ are endemic to the region. Many species have very restricted ranges within the region. There is a decline in diversity and local endemism from south to north. The southernmost division $\left(8-12^{\circ} \mathrm{N}\right)$ has much the richest recorded fauna ( 210 species), and the highest level of local endemism (56\%). The latter is much lower in the central $\left(12-16^{\circ} \mathrm{N}\right)$ and northern $\left(16-21^{\circ} \mathrm{N}\right)$ divisions. There is thus considerable faunal turnover within the region. The overall level of endemism is higher than that recorded for other taxa, and our data have already been used to identify three local hotspots within the region. These results are discussed in terms of present climate and habitats, and in terms of environmental history. Comparisons are made with studies on other continents, and the impact of human activity by destruction and fragmentation of habitats is considered.
\end{abstract}

Key words: Land snail distribution, Western Ghats, endemism, species diversity

\section{INTRODUCTION}

Although conservation of biological diversity as a whole is now a matter of global concern, most analyses, effort and resources have been allocated to charismatic mammals and birds. In the Indian context, this is evident from the setting aside of large area of habitats as protected areas (PAs) where such animals are known to occur (Uma Shaanker et al., 2004). In general, invertebrate species have been neglected despite their far greater numbers, and despite the fact that recent evidence shows that they can be more reliable indicators of "hotspots" of high diversity and endemism overall (Moritz et al, 2001). Efficient conservation planning requires awareness of invertebrate distribution, diversity and endemism patterns.

India has two internationally recognised biologically rich areas, one being Eastern Himalaya and the other being the Western Ghats. The Western Ghats, coupled with Sri Lanka, is one of the twentyfive prime hotspots of the world (Myers, 1988; Myers et al, 2000), and is known for its rich flora and fauna with a high degree of endemism (Groombridge, 1992). Existing knowledge of distribution and habitats is, however, largely concentrated on birds, plants, amphibians and fishes (Ali, 1935; Daniels, 1992; Dahanukar et al., 2004; Ramesh and Pascal, 1996). The region is undergoing rapid transformation due to anthropogenic activities (Jha et al., 2000), making the identification and protection of key areas an urgent priority. As Moritz et al. (2001) have shown, land snails are very good indicators of conservation importance and of centers of endemicity, and they can be used to identify significant localities at much smaller scale than those identified by studies on vertebrates.

Unfortunately, there have been few modern studies of land snail distribution in India, even though it is known to have hotspots of molluscan diversity. Most data come from the Fauna of British India, published between 1908 and 1921. Later studies are few. Although one recent study has tried to assess the diversity of land snails in Western Ghats based on earlier literature (Madhyastha et al., 2004), there are no modern data available on the distribution and endemicity of this group. In this study, we report the results of new fieldwork, and use our results, together with earlier work to: (a) identify areas of high species richness and endemicity of land snails in Western Ghats; (b) compare the endemicity of land snails with that of 
other groups, and (c) determine the distributional patterns of land snails in Western Ghats.

\section{MATERIALS AND METHODS}

\section{Study area}

The Western Ghats region is a mountain chain running for $1,600 \mathrm{~km}$ parallel to the west coast of
India from the river Tapti (Gujrat) in the north, to Kanyakumari (Tamil Nadu) in the south, between the latitudes $8{ }^{\circ} \mathrm{N}$ to $21^{\circ} \mathrm{N}$, and covering an area of about $160,000 \mathrm{~km}^{2}$ (Daniels, 2004). The continuity of this hill chain is interrupted by the $30 \mathrm{~km}$ wide 'Palghat Gap' near $11^{\circ} \mathrm{N}$ (Figure 1). Between the Arabian Sea to the west and the mountains to the east is a coastal region of varying width ranging from 30 to $60 \mathrm{~km}$. The narrowest strip is at latitude

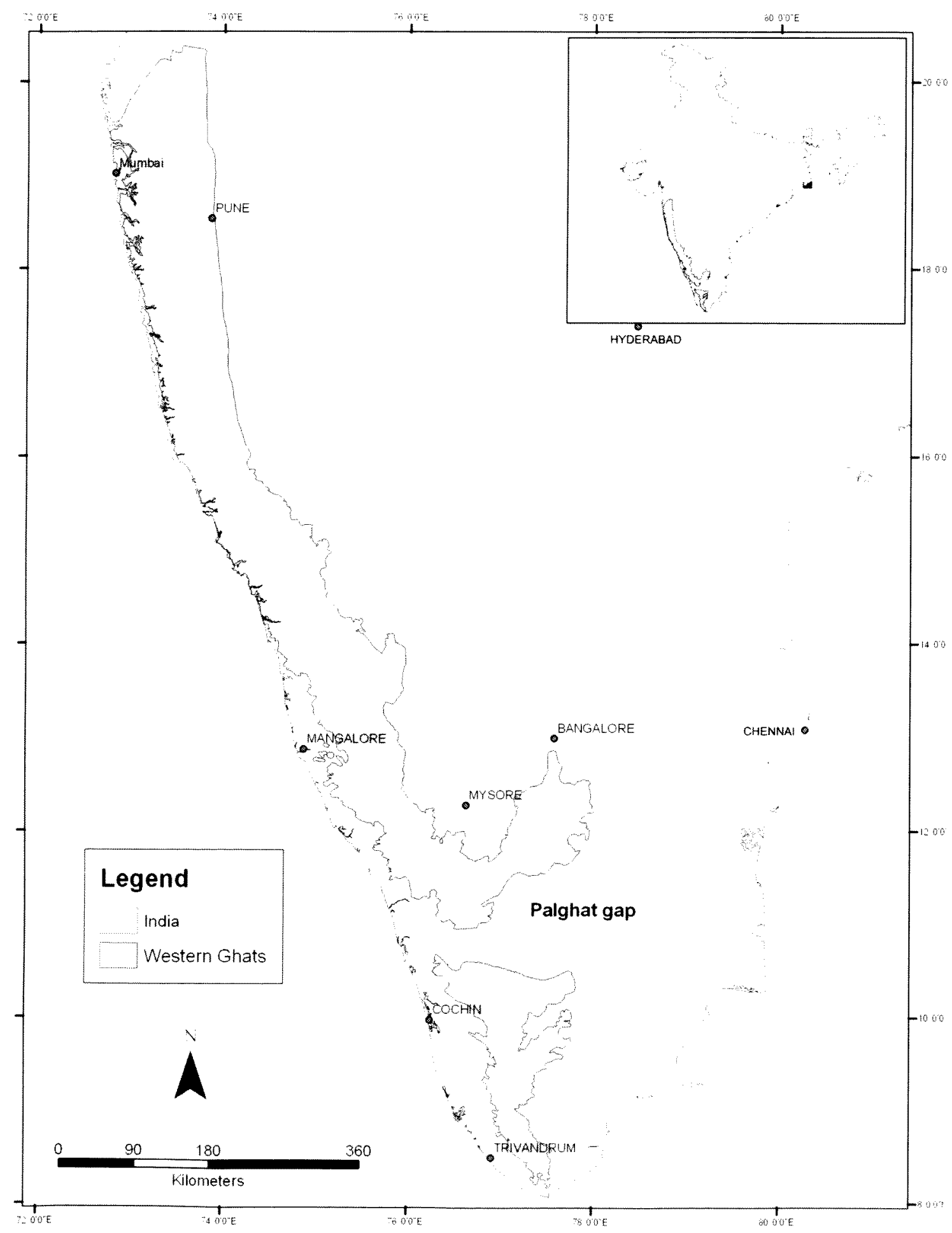

Figure 1 Map showing the location of the Western Ghats hotspot in India 
$14^{\circ}$ and $15^{\circ} \mathrm{N}$ where the Ghats are close to the west coast. Rising from the coastal strip, the mountains reach $2,800 \mathrm{~m}$ at the highest peak. High peaks above $2,000 \mathrm{~m}$ are found in the Nilgiris, Anamalais and Palnis in the southern region. To the east, the mountains descend to plains at about $600 \mathrm{~m}$. Different regions of the Western Ghats receive varying amounts of rainfall ranging from less than $1,000 \mathrm{~mm}$ to more than $7,600 \mathrm{~mm}$ per annum (Agumbe, Karnataka), with an average of $2,500 \mathrm{~mm}$ (Gadgil, 1996). The bulk of the rainfall is received in the southwest monsoon between June and October, but the rainy season in the south is often prolonged due to pre-monsoon and winter showers. Thus, the dry periods in the southern parts of the Western Ghats are shortest, lasting for 2 to 5 months while in the northern parts it varies from 5 to 8 months. Mean annual temperature ranges between $20^{\circ}$ and $24^{\circ} \mathrm{C}$. However, it frequently reaches beyond $30^{\circ} \mathrm{C}$ during April-May and sometimes falls to $0^{\circ} \mathrm{C}$ during winter at the higher altitudes (Dahanukar et al., 2004).

Further details of geology, biodiversity and ecological history of the Western Ghats are available elsewhere (Chandran, 1997; Gadgil, 1994, 1996; Valdiya, 2002; Daniels, 2004). The combination of particular environmental and historical factors make the Western Ghats an area of exceptional biological diversity and conservation interest, and it is "one of the major Tropical Evergreen Forest regions in India" (Rodgers and Panwar, 1988). The landscape of the Western Ghats has undergone a great change over the past century. The nature, extent and cause of the transformation have been debated extensively (Gadgil, 1996). The high rate of human population growth, infiltration into forests through roads, dams and expansion of agriculture has reduced forest cover drastically. According to Cincotta et al. (2000), human population pressure in the Western Ghats will continue to rise which is in their highest category of risk and could lead to future extinctions in this region.

\section{Data sources}

The land snail data regarding the richness, diversity, endemism and distribution in the Western Ghats were obtained from various published sources and our own field analysis. The major source of published information was Fauna of British India: Mollusca (Blanford and Godwin-Austen, 1908; Gude, 1914 and 1921). Some additional data come from Sathyamurthi (1960), Tonapi and Mulherkar (1963), Subbarao and Mitra (1979), and Ramakrishna and Mitra (2002). Apart from the published sources we have also included the data on land snails from nine sites from the Western Ghats for the present analysis (Table 1). In each study site, we collected the data such as number of species, habitat in which the species was recorded, altitude, latitude and longitude (using Garmin GPS Map 76s) and number of individuals of each species using the sampling method described in Emberton (1996). However, we have not used the abundance data for the present analysis. A total of 15 new locality records for species were added, but no new species have been added to the overall list. The classification we followed is of Vaught (1989). However, we split the family Subulinidae into Glessulidae and Subulinidae.

\section{Methods}

All reliable records, old and new, have been entered into a database which is continuously updated. Information entered includes data (where available) on family, species, latitude, altitude, size, endemic, non-endemic, year of discovery of the species, and locality. Early records are not always precisely located. Because of this, we have held back any analysis of relationships between the snail fauna and altitude, although we believe such relationships exist. For the same reason, there are some records for which we have had to make assumptions about the latitude and longitude, taking into account the latitude and longitude of the nearest named place. While this may result in a

Table 1 Sites, region, latitude and number of land snail species.

\begin{tabular}{|c|c|c|c|c|}
\hline Site & Region & $\begin{array}{l}\text { Latitude } \\
\left({ }^{\circ} \mathrm{N}\right)\end{array}$ & $\begin{array}{l}\text { No. of } \\
\text { species }\end{array}$ & References \\
\hline Agumbe & Karnataka & $13^{\circ} 30^{\prime}$ & 22 & Aravind unpublished \\
\hline Aralasurali & Karnataka & $13^{\circ} 48^{\circ}$ & 18 & Aravind unpublished \\
\hline Nagara & Karnataka & $13^{\circ} 47^{\prime}$ & 25 & Aravind unpublished \\
\hline $\begin{array}{l}\text { Biligiri Rangaswamy Temple } \\
\text { Wildlife Sanctuary (BR Hills) }\end{array}$ & Karnataka & $\begin{array}{l}11^{\circ} 47^{\prime} \text { to } \\
12^{\circ} 09^{\prime}\end{array}$ & 23 & Aravind unpublished \\
\hline $\begin{array}{l}\text { Rajiv Gandhi (Nagarahole) } \\
\text { National Park }\end{array}$ & Karnataka & $\begin{array}{l}11^{\circ} 45^{\prime} \text { to } \\
12^{\circ} 15^{\prime}\end{array}$ & 41 & Ganeshet al., 2002 \\
\hline Kudremukh National Park & Karnataka & $13^{\circ} 01^{\prime}$ to $13^{\circ} 29^{\prime}$ & 73 & Madhyastha et al. personal communication \\
\hline Sharavathi Wildlife Sanctuary & Karnataka & $13^{\circ} 42^{\prime}$ to $14^{\circ} 00^{\prime}$ & 22 & Mavinkuruve et al. in press \\
\hline Madikeri & Karnataka & $12^{\circ} 25^{\prime}$ & 62 & Mavinkuruve et al. unpublished \\
\hline $\begin{array}{l}\text { Kalakkad-Mundanthurai Tiger } \\
\text { Reserve (KMTR) }\end{array}$ & Tamil Nadu & $08^{\circ} 20^{\prime}$ to $08^{\circ} 53^{\prime}$ & 25 & Mavinkuruve et al. unpublished \\
\hline
\end{tabular}


few misattributions, we are confident that the results of our analyses are robust overall.

For analysis we split the Western Ghats into three latitudinal divisions: north (between $16^{\circ}$ and $21^{\circ} \mathrm{N}$ ), central (between $12^{\circ}$ and $16^{\circ} \mathrm{N}$ ) and south (between $8^{\circ}$ and $12^{\circ} \mathrm{N}$ ), following Ramesh and Pascal (1996), Subramanian and Shivaramakrishnan (2002) and Danankar et al. (2004). Sorensen's similarity index (using presence and absence data) was used to assess the similarity between the faunas in latitudinal bands.

\section{RESULTS}

\section{Species diversity and endemism of land snails of} the Western Ghats

To date, 1,488 species belonging to 26 families and 140 genera have been recorded from India (Wiktor et al., 1999; Ramakrisha and Mitra, 2002; Madhyastha et al., 2004). Of these, 269 species of land snails have been recorded from the Western Ghats area and constitute about 18 per cent of the country's total land snail fauna. The land snail fauna of the Western Ghats includes members of 24 families and 57 genera (Madhyastha et al., 2004; Table 2). Three families viz., Glessulidae (56

Table 2 Comparison of land snail diversity of the Western Ghats with India

\begin{tabular}{lccc}
\hline & $\begin{array}{c}\text { Occurrence in } \\
\text { India }\end{array}$ & $\begin{array}{c}\text { Occurrence in } \\
\text { Western Ghats }\end{array}$ & Percentage \\
\hline Families & 26 & 24 & 92.31 \\
Genera & 140 & 57 & 40.71 \\
Species & 1,488 & 269 & 18.10 \\
\hline
\end{tabular}

species), Cyclophoridae (54 species) and Ariophantidae (53 species) dominate the assemblage. These three families together constitute 63 per cent of the species of Western Ghats. 204 of the 269 species, c. 76 per cent, are endemic to Western Ghats. Indrella (Ariophantidae) a monospecific genus is restricted to the Western Ghats (Front cover).

\section{Distribution patterns of land snails in the Western Ghats}

Figure 2 shows the numbers of species recorded in the three major divisions of the region. The south is decisively the most species-rich with 210 species overall, followed by central and north with 85 and 62 species respectively. There is a high rate of species turnover within the region. Only 15 species are found in all three major divisions (north, central and south), and of these only five are widespread within each. 101 species are currently known only from one locality each; while this may reflect deficiencies in surveying intensity, it is clear that many ranges are very restricted. Comparisons of faunal similarity between $2^{\circ}$ latitudinal bands, using the Sorensen index (Table 3 ), shows a rapid rate of faunal change. This is partly due to the decline in diversity northwards. The latitude range between $10^{\circ}$ and $12^{\circ} \mathrm{N}$ harbours nearly 65 per cent of the land snails of the Western Ghats, and there is a significant decrease in the species richness ( $r=-$ $0.737, \mathrm{p}<0.001$, Figure 3a) and number of families from south to north $(r=-0.743, \mathrm{p}<0.001)$. Seven families are found throughout the Western Ghats, whereas three families are restricted to latitude $10^{\circ}$ to $12^{\circ} \mathrm{N}$ and two families to $18^{\circ}-20^{\circ} \mathrm{N}$. The same trend is seen in both endemic $(r=-0.747, \mathrm{p}<0.001)$

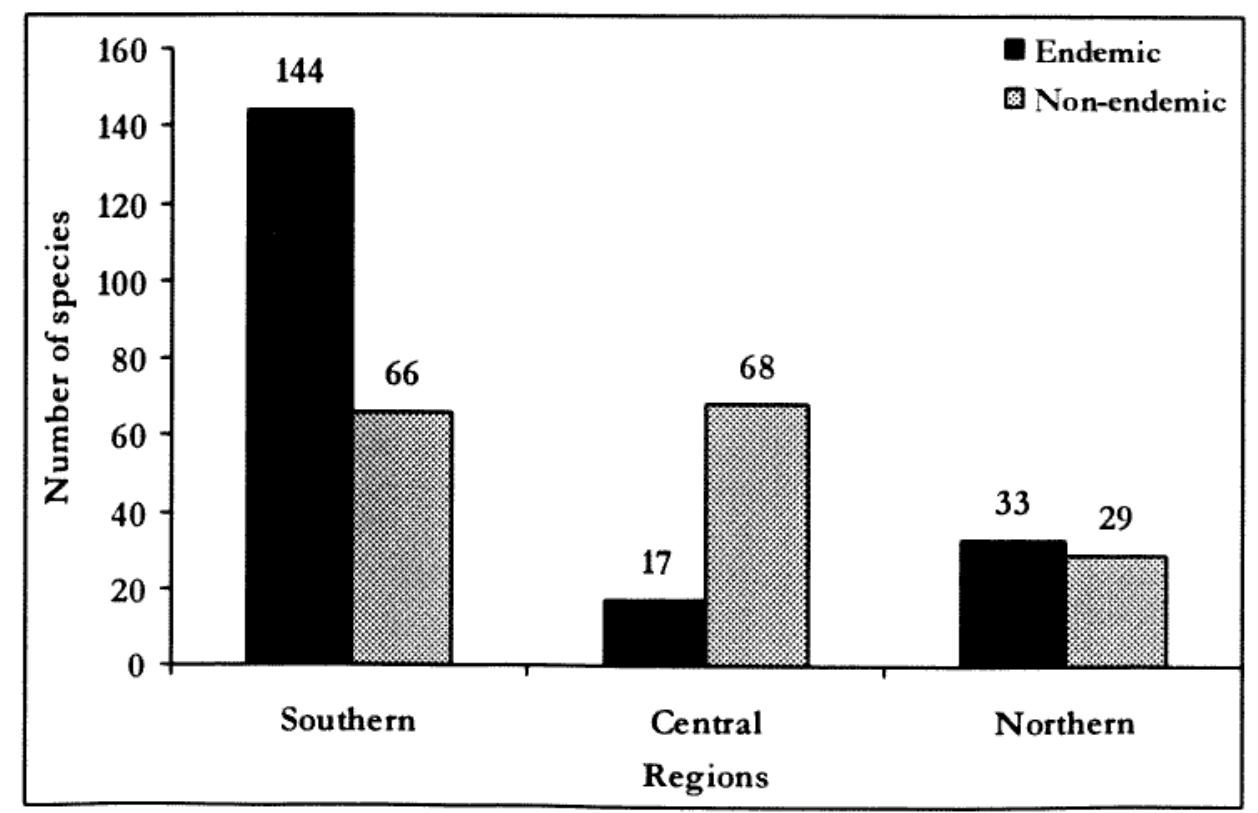

Figure 2 Distribution of endemic and non-endemic species in three regions of the Western Ghats, India 
Table 3 Sorensen's similarity index between different latitude ranges in the Western Ghats and number of species recorded in each latitudinal band.

\begin{tabular}{|c|c|c|c|c|c|c|c|c|}
\hline Latitude $\left({ }^{\circ} \mathrm{N}\right)$ & $08-10$ & $10-12$ & $12-14$ & $14-16$ & $16-18$ & $18-20$ & $20-22$ & No. of species \\
\hline 08-10 & 1.00 & & & & & & & 103 \\
\hline $10-12$ & 0.46 & 1.00 & & & & & & 169 \\
\hline $12-14$ & 0.31 & 0.36 & 1.00 & & & & & 59 \\
\hline $14-16$ & 0.22 & 0.13 & 0.34 & 1.00 & & & & 24 \\
\hline $16-18$ & 0.18 & 0.16 & 0.36 & 0.49 & 1.00 & & & 29 \\
\hline $18-20$ & 0.16 & 0.15 & 0.19 & 0.28 & 0.40 & 1.00 & & 56 \\
\hline $20-22$ & 0.11 & 0.07 & 0.15 & 0.30 & 0.21 & 0.22 & 1.00 & 9 \\
\hline
\end{tabular}

a

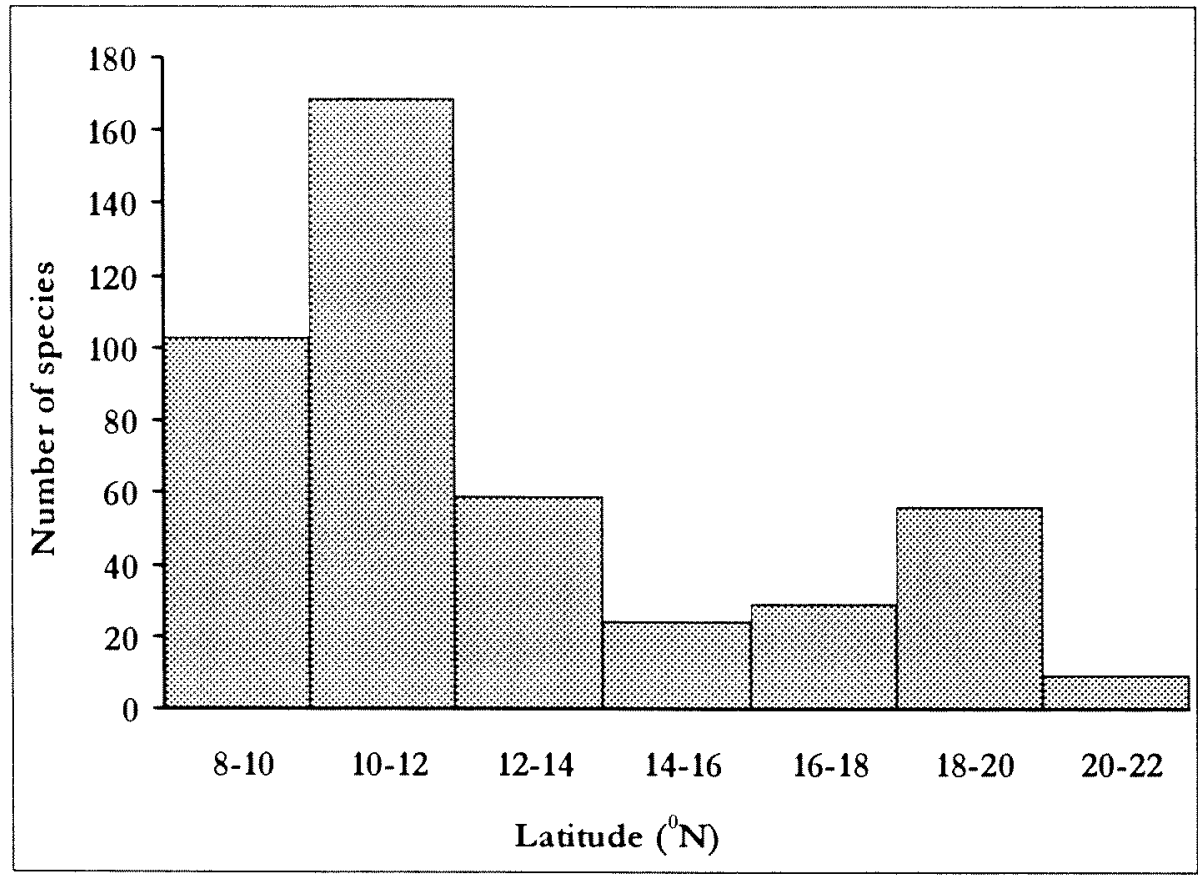

b

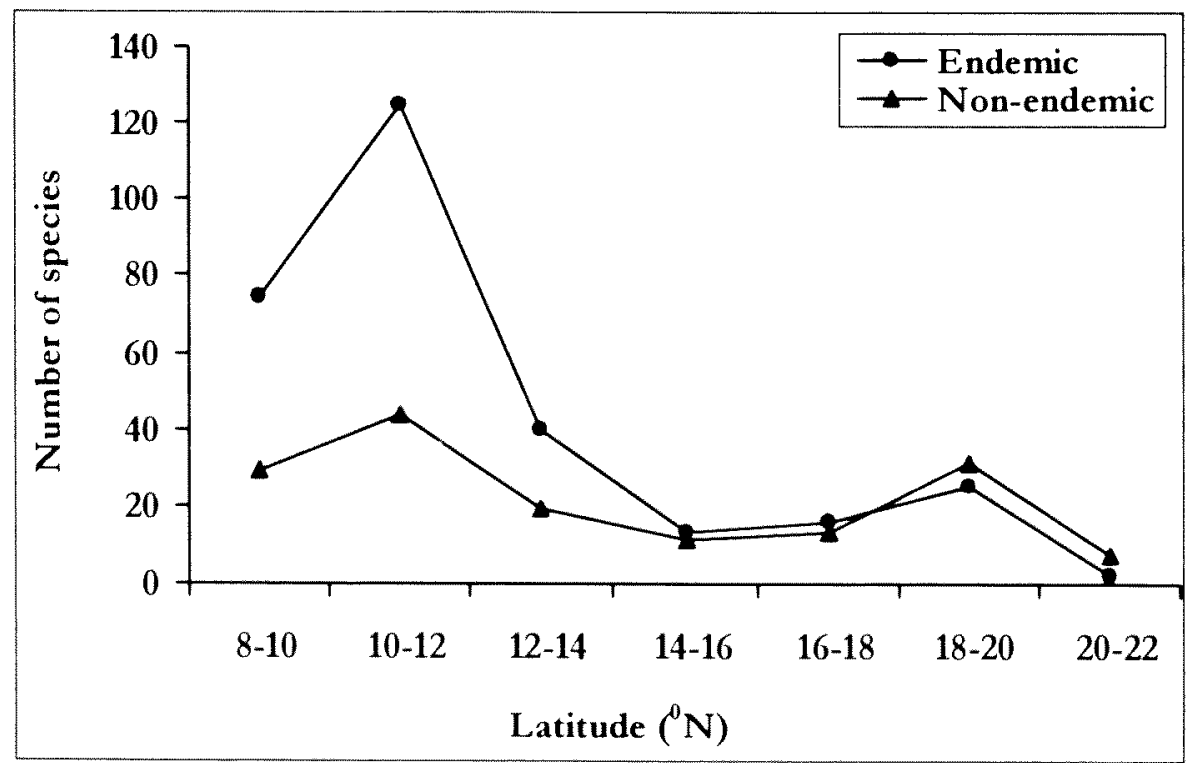

Figure 3 a) Number of land snail species found in different latitudinal ranges and b) number of endemic and nonendemic species of land snails found in different latitudinal ranges in the Western Ghats 
and non-endemic species $(r=-0.628, \mathrm{p}<0.002)$, but the proportion of non-endemic species increases from south to north (Figure $3 b$ ).

Several distinct distributional patterns can be seen in the Western Ghats fauna. Species may be restricted to one or two contiguous divisions within the Western Ghats, they may be found in all three, and beyond. They may show a discontinuous or disjunct distribution within the Western Ghats, while some occur within the region and also in far distant regions with a gap in distribution between. For example, Ennea bicolor (Streptaxidae) and Kaliella barrakporensis (Helicarionidae) are tropical cosmopolitan species and found throughout the Western Ghats, whereas the monotypic genus Indrella ampulla (Ariophantidae) is found only between $10^{\circ}$ and $13^{\circ} \mathrm{N}$ latitude (Front cover). Several species show very restricted distributions. For example, the amphibious species, Lithotis rupicola (Succineidae) is found only near waterfalls near Khandala, Northern Western Ghats, Glessula calkadensis is restricted to the southern Western Ghats and Glessula orophila shows a discontinuous distribution within the region and the genus Crapedotropis shows a discontinuous distribution, with species occurring in Western Ghats, Eastern Ghats and North-eastern India, but not in between.

\section{DISCUSSION}

The results presented here on diversity, endemism and distribution of land snails of the Western Ghats are, inevitably, heavily influenced by variation in the completeness of the sampling effort. The southernmost region of the Western Ghats, between $8^{\circ}$ and $12^{\circ} \mathrm{N}$, is relatively better sampled than the other areas. To date, only 269 species have been recorded from the Western Ghats. With ongoing work, the rate of discovery of new species remains high, and we have no firm basis for predicting the actual number of species present in the region. Evidence from incompletely surveyed tropical and subtropical forest regions on other continents suggests that 500 or more species could be present (Stanisic, 1994; Tattersfield, 1998). The smaller area of Sri Lanka, to the south, has more than 350 species, and is still incompletely surveyed (Naggs and Raheem, this volume). Most records of new species and new localities for known species may come from regions between $12^{\circ}$ and $16^{\circ} \mathrm{N}$, as this area is the least surveyed. This applies also to fishes and amphibians (Dahanukar et al., 2004; Gururaja, personal communication).

However, some general conclusions can be drawn. As in some other studies (Moritz et al., 2001), endemism in snails is higher (at c. 75\%) than in other taxa in the Western Ghats (Subramanian and Shivaramakrishnan, 2002) and there are many very restricted endemics with tiny ranges. Existing knowledge has enabled us already to identify three regions of high species richness and endemism in each of the three divisions: the Nilgiris-AnnamalaisPalni hills-Travancore region in southern Western Ghats, the South Kanara-North Kanara region in central Western Ghats, and the MahabaleshwarKhandala-Poona region in northern Western Ghats (Aravind et al., in preparation).

On the evidence available at present, the southern Western Ghats (below $12^{\circ} \mathrm{N}$ ) are more diverse than areas further north. This pattern is also true for other groups such as fishes (Dahanukar et al., 2004), endemic plants (Ramesh and Pascal, 1996), and Odonata (Subramanian and Shivaramakrishnan, 2002). However, for amphibians and aquatic insects, the latitudes between $12^{\circ}$ and $14^{\circ} \mathrm{N}$ are richest (Daniels, 1992; Subramanian, 2004). Trends for decreasing regional diversity at higher latitudes are also found elsewhere, for example in New Zealand (Barker, this volume), North America (Nekola, this volume) and in Europe (Cameron, 2004). There may be diverse reasons for this pattern; in the Western Ghats, it seems likely that the combination of a favourable rainfall regime in the south, the presence of high mountains, and a great diversity of habitats contribute to the pattern. In Sri Lanka, the region of highest diversity and local endemism is in the southwest of the island, the area of highest rainfall, with relict stands of rainforest (Naggs and Raheem, 2005).

Several species of land snails are sporadically distributed along the Western Ghats. No doubt some of this patchiness is a product of the unevenness of effort throughout the range of the Ghats. The patchiness in the distribution, however, is not unique to land snails; a similar pattern has been shown for amphibians and birds of the Western Ghats (Ali, 1935; see Daniels, 1992). For example, Glessula orophila (Glessulidae) occurs in scattered sites in southern, central and northern Western Ghats. It seems likely that this patchy distribution is a result of local extinction and poor dispersal ability (Diamond, 1973; Daniels, 1992). It has been shown that the Western Ghats has a long history of human impact (Chandran, 1997). The major change in the landscape has occurred in the moist evergreen forests. The vast original extent of this forest type has been reduced and fragmented by a variety of other land use types (Nair and Daniel, 1986; Daniels et al., 1990; Daniels, 1992). This habitat fragmentation, coupled with geological and climatic history, might have created the patchy distribution of some land snails and other taxa of the Western Ghats (Ali and Ripley, 1983; Daniels, 1989, 1992).

Our observations so far reveal the broad pattern of diversity, endemism and geographical distribution of land snails of the Western Ghats. It is clear that, as in other mountainous tropical 
regions, the land snail fauna is rich, and largely endemic. Further studies are required to get better insight into the patterns and processes of land snail distribution in this hotspot of biodiversity, studies which will contribute directly to good conservation planning.

\section{ACKNOWLEDGEMENTS}

The work presented here is in part supported by the International Foundation for Science, Sweden, the Edda G. Sehgal Foundation, Washington, and Karnataka Forest Department, Bangalore to N. A. Aravind. We are grateful to Mr. Bipin Charles and Mr. K. Srinivasan for many kinds of help. We thank the editors and an anonymous referee for helpful suggestions.

\section{REFERENCES}

Ali, S. (1935). The ornithology of Travancore and Cochin. Journal of Bombay Natural History Society 37: 814-843.

Ali, S. and Ripley, S. D. (1983). Handbook of the Birds of India and Pakistan (compact edition). Oxford University Press, New Delhi.

Barker, G.M. (2005). The character of the New Zealand land snail fauna and communities: some evolutionary and ecological perspectives. Records of the Western Australian Museum Supplement 68: 53-102.

Blanford, W. T. and Godwin-Austen, H. H. (1908). The Fauna of British India - Including Ceylon and Burma Mollusca I. Taylor and Francis, London.

Cameron, R.A.D. (2004). From continents to quadrats: species/area relationships in land mollusc faunas. Journal of Conchology, Special Publication 3: 39-54.

Chandran, M. D. S. (1997). On the ecological history of the Western Ghats. Current Science 73: 146-155.

Cincotta, R. P., Wisnewski, J. and Engelman, R. (2000). Human population in the biodiversity hotspots. Nature 404: 990-992.

Dahanukar, N., Raut, R. and Bhat, A. (2004). Distribution, endemism and threat status of freshwater fishes in the Western Ghats of India. Journal of Biogeography 31: 125-136.

Daniels, R. J. R. (1989). A Conservation Strategy of the Birds of the Uttara Kannada District. PhD Thesis, Indian Institute of Science, Bangalore.

Daniels, R. J. R. (1992). Geographical distribution patterns of amphibians in the Westren Ghats, India. Journal of Biogeography 19: 521-529.

Daniels, R. J. R. (2004). Biodiversity of the Western Ghats: An overview. In A. K. Gupta, A. Kumar and V. Ramakantha (eds), ENVIS Bulletin: Wildlife and Protected Areas, Conseruation of Rainforest in India 4:2540.

Daniels, R. J. R., Joshi, N. V. and Gadgil, M. (1990). Changes in the bird fauna of Uttara Kannada, India, in relation to changes in land use over the past century. Biological Conservation 52: 37-48.

Diamond, J. (1973). Distributional ecology of New Guinea birds. Science 179: 759-769.
Emberton, K. C. (1996). Conservation priorities for forestfloor invertebrates of the southeastern half of Madagascar: evidence from two land snails. Biodiversity and Conservation 5: 729-741.

Gadgil, M. (1994). Conserving the biodiversity of the Western Ghats as if people matter. Current Science $\mathbf{6 6}$ 184.

Gadgil, M. (1996). Western Ghats: A lifescape. Journal of Indian Institute of Sciences 76: 495-504

Ganesh, T., Priyadarsanan, D. R., Devy, M. S., Aravind, N. A. and Rao, D. (2002). Assessment of Biodiversity of Lesser-known and Functionally Important Groups in Rajiv Gandhi (Nagarahole) National Park. Report: Submitted to Karnataka Forest Department, Bangalore, India.

Groombridge, B. (ed.) (1992). Global Biodiversity - Status of the Earth's Living Resources: a World Conservation Monitoring Centre Report. Chapman and Hall, London.

Gude, G. K. (1914). The Fauna of British India - Including Ceylon and Burma - Mollusca II. Taylor and Francis, London.

Gude, G. K. (1921). The Fauna of British India - Including Ceylon and Burma - Mollusca III. Taylor and Francis, London.

Jha, C. S., Dutt, C. B. S. and Bawa, K. S. (2000). Deforestation and land use changes in Western Ghats, India. Current Science 79: 231-238.

Madhyastha, N. A., Mavinkuruve, R. G. and Shanbhag, S. P. (2004). Land snails of Western Ghats. In A. K. Gupta, A. Kumar and V. Ramakantha (eds), ENVIS Bulletin: Wildlife and Protected Areas, Conservation of Rainforest in India 4: 143-151.

Mavinkuruve, R. G., Shanbhag, S. P. and Madhyastha, N. A. (2004). The land snails of Sharavathi wildlife sanctuary. Records of Zoological Survey of India 104 (Parts 1-2): 123-131.

Moritz, C., Richardson, K.S., Ferrier, S., Monteith, G.B., Stanisic, J., Williams, S.E. and Whiffin, T. (2001). Biogeographical concordance and efficiency of taxon indicators for establishing conservation priority in a tropical rainforest biota. Proceedings of the Royal Society of London, B 268: 1875-1881.

Myers, N. (1988). Threatened biotas: "Hotspots" in tropical forests. Environmentalist 8: 1-20.

Myers, N., Mittermeier, R. A., Mittermeier, C. G., da Fonseca, G. A. B. and Kent, J. (2000). Biodiversity hotspots for conservation priorities. Nature 403: 853 858.

Naggs, F. and Raheem, D. (2005). Sri Lankan snail diversity: faunal origins and future prospects. Records of the Western Australian Museum Supplement 68: 1129.

Nair, N. C. and Daniel, J. C. (1986). The floristic diversity of the Western Ghats and its conservation: a review. Proceedings of Indian Academy of Sciences. (Animal Science/Plant Science), Supplement: 127-163.

Nekola, J. C. (2005). Geographic variation in richness and shell size of eastern North American land snail communities. Records of the Western Australian Museum Supplement 68: 39-51.

Ramakrishna and Mitra, S. C.. (2002). Endemic land molluses of India. Records of Zoological Survey of India, Occasional Paper 196: 1-65. 
Ramesh, B. R. and Pascal, J. P. (1996). Distribution of endemic arborescent evergreen species in the Western Ghats. In C. K. Karunakaran (ed.), The Proceedings of the Symposium on Rare, Endangered and Endemic Plants of the Western Ghats. Kerala Forest Department, special Publication No. III, Thiruvananthapuram. pp. 20-29.

Rodgers, W. A. and Panwar, H. S. (1988). Planning a Wildlife Protected Area Network in India. Vol. I. Wildlife Institute of India, Dehradun.

Sathyamaurthi S. T. (1960). The land and freshwater mollusca in the collection of the Madras Government Museum. Bulletin of the Madras Government Museum, 6 (4): $1-174$.

Stanisic, J. (1994). The distribution and patterns of species diversity of land snails in eastern Australia. Memoirs of the Queensland Museum 36: 207-214.

Subbarao, N. V. and Mitra, S. C. (1979). On the land and freshwater molluscs of Pune district, Maharastra. Records of Zoological Survey of India 75: 1-37.

Subramanian, K. A. (2004). Community composition and bio-monitoring potential of hill stream insects of the Western Ghats. Sahyadri E-news Issue 5. Web: http:// ces.iisc.ernet.in/wgbis/envis/.

Subramanian, K. A. and Shivaramakrishnan, K. G. (2002). Conservation of odonate fauna in Western Ghats - a biogeographic perspective. In K. P. Sanjayan, V.
Mahalingam and M. C. Muralirangan, (eds), Vistas of Entomological Research for the New Millennium, G.S. Gill Research Institute, Chennai. pp. 11-22.

Tattersfield, P. (1998). Patterns of diversity and endemism in East African land snails, and the implications for conservation. Journal of Conchology, Special Publication 2: 77-86.

Tonapi, G. T. and Mulherkar, L. (1963). Studies on freshwater and amphibious molluscs of Poona with notes on their distribution - Part II. Journal of Bombay Natural History Society 60: 103-120.

Uma Shaanker, R., Aravind, N. A. and Ganeshaiah, K. N. (2004). Forest management for conservation. In J. J. Burley, J. Evans and J. A. Youngquist (eds), Encyclopedia of Forest Sciences, Vol. II. Elsevier Science, London. pp. 215-224.

Valdiya, K. S. (2002). Tectonic resurgence of the Mysore plateau and surrounding regions in cratonic Southern India. Current Science 81: 1068-1089.

Vaught, K. C. (1989). A classification of the Living Mollusca. American Malacologists Inc., Melbourne, USA.

Wiktor, A., Naggs, F. and Gupta, P. K. (1999). Turcomilax (Taulimax) oli sp. n. from the Kumaun Himalaya, India (Gastropoda: Pulmonata: Limacidae). Malakologische Abhandlungen Staatliches Museum fiir Tierkunde Dresden 19: 225-231. 